\title{
TRADISI PATANGKILAN BARONG DI PURA PENATARAN AGUNG PURI AGUNG SINGAPADU GIANYAR
}

\author{
Oleh: \\ A.A Dwi Dirgantini \\ dwidirgantini@unhi.ac.id \\ I Made Sudarsana \\ sudarsana@unhi.ac.id \\ Universitas Hindu Indonesia Denpasar
}

\begin{abstract}
ABSTRAK
Tradisi Patangkilan Barong di Pura Penataran Agung Puri Agung Singapadu, Kecamatan Sukawati, Kabupaten Gianyar merupakan salah satu tradisi yang masih berlangsung hingga kini dan memperlihatkan kompleksitas nilai-nilai spiritual, sosial, seni dan budaya masyarakat Bali. Penelitian ini dilakukan untuk mengetahui alasan dipilihnya waktu tertentu, prosesi ritual pelaksanaannya, serta nilainilai seni dan budaya yang terdapat dalam pelaksanaan Patangkilan Barong. Penelitian ini menggunakan metode kualitatif dan menekankan kepada analisis deskriptif. Dari penelitian yang diperoleh bahwa pelaksanaan Tradisi Patangkilan Barong adalah berdasarkan syarat dari undagi atau sangging dan tempat pasupati dimana barong-barong yang ngerauhin atau lunga sinarengan adalah pekaryan atau buah karya Ida Tjokorda Api dan penerusnya, Ida Dwagung Geni serta Ida Dwagung Singapadu. Nilainilai Pendidikan, seni dan budaya yang dapat diambil dari pelaksanaan Patangkilan Barong di Pura Penataran Agung Singapadu berlandaskan kesatuan sosial antar panyungsung dari berbagai daerah, adanya semacam festival budaya di jaba sisi Pura, dimana setiap sesuhunan mesolah diiringi juru bapang dan penabuh dari daerahnya masing-masing. Keberadaan barong dan rangda sebagai karya seni ritual adiluhung buatan Puri Singapadu menjadi sumber inspirasi bagi para sangging dan pengrajin topeng di Singapadu dan sekitarnya serta sebagai nilai pemersatu dan nilai religius magis. Hal inilah yang menyebabkan pelaksanaan yadnya di Pura Penataran Agung Singapadu semakin bermakna.
\end{abstract}

Kata kunci: Patangkilan Barong Pura Penataran Agung Singapadu, seni dan budaya

\section{ABSTRACT}

The Patangkilan Barong tradition at Penataran Agung Temple Puri Agung Singapadu, Sukawati, Gianyar is one of the traditions that is still ongoing today and shows the complexity of the spiritual, social, artistic and cultural values of the Balinese people. This research was conducted to determine the reasons for choosing a certain time, the ritual procession for its implementation, as well as the artistic and cultural values contained in the implementation of Patangkilan Barong. This research uses qualitative methods and emphasizes descriptive analysis. Based on the research, it is found that the implementation of the Patangkilan Barong Tradition is based on the terms of the undagi or sangging and the place of the pasupati where the barongs who ngerauhin or lunga sinarengan were the work of Ida Tjokorda Api and his successors, Ida Dwagung Geni and Ida Dwagung Singapadu. The educational, artistic and cultural values taken from the implementation of Patangkilan Barong at Pura Penataran Agung Singapadu are based on social unity between panyungsung from various regions, there is a kind of cultural festival on the outer yard of the temple, where each sesuhunan masolah is accompanied by bapang player and musician from their respective regions. The existence of the barong and the rangda as works of art rituals made by Puri Singapadu are sources of inspiration for the dancers and mask craftsmen in Singapadu and its surroundings as well as a unifying value and magical religious value. This is what makes the implementation of the yadnya at Pura Penataran Agung Singapadu even more meaningful.

Keywords: Patangkilan Barong Pura Penataran Agung Singapadu, art and culture 


\section{PENDAHULUAN}

Tradisi adalah segala sesuatu (seperti adat, kepercayaan, kebiasaan, ajaran) yang turun-temurun dan sudah menjadi kebiasaan yang dilakukan secara berulang-ulang dari nenek moyang. Keberlangsungan tradisi dari zaman dahulu yang lestari hingga kini dikarenakan adanya kehidupan yang harmonis, aman, tentram, dan tentunya ditunjang oleh kesejahteraan pelakunya.

Dalam tradisi Hindu ada istilah : Vasudeva kutumbhakam. Artinya semua mahluk di dunia ini bersaudara. Kalau ada dalam suatu masyarakat atau golongan tertentu yang tidak merasa bersaudara dengan golongan lain karena berbeda, tentunya akan memendam potensi konflik yang laten. Demikian juga dalam kebersamaan harus ada kemerdekaan untuk melakukan sesuatu tanpa ada penekan. Kemerdekaan tentunya tidak sama dengan kebebasan tanpa batas. Kemerdekaan tetaplah berdasarkan norma-norma yang disepakati bersama melalui proses demokrasi berdasarkan kearipan yang mulia. Seiring perubahan jaman belakangan ini kearifan lokal masyarakat sudah mulai terkikis. Itu terbukti banyaknya terjadi ketidak harmonisan antar saudara. Masyarakat jaman sekarang lebih cepat terprovokasi isu hoak dan dengan gampang tangannya menekan tombol hpnya tanpa sadar menyebarkannya di media sosial ketimbang menelusuri sumber beritanya. Misalnya bagaimana isu-isu tentang Hare Krisna yang belum terselesaikan hingga kini dan isu pelaksanaan protokol covid 19 yang berbeda-beda sehingga menimbulkan ketidakpastian terhadap pelaksanaan upacara adat maupun agama yang menyebar di media sosial sehingga memendam konflik di masyarakat Bali, sehingga perlu disikapi dengan bijak bagaimana nilai positif warisan budaya leluhur yang mampu bertahan hingga kini yang tentunya melalui adaptasi dan pengembangan sehingga mampu lestari sesuai dengan nuansa jaman.

Masyarakat Hindu di Bali pada beberapa daerah hingga kini masih mempertahankan tradisi pada waktu-waktu tertentu untuk membawa dan mempertemukan benda-benda sakral seperti barong dan rangda, yang merupakan bendabenda keramat yang sangat disucikan dan disakralkan masyarakat ke pura tertentu yang oleh warga masyarakat setempat dipercaya memiliki aura taksu yang luar biasa. Tradisi Patangkilan Barong adalah mempertemukan benda-benda sakral seperti barong dan rangda. Tradisi mempertemukan benda-benda sakral seperti barong dan rangda, seperti di Desa Adat Tegal Badung, di Desa Adat Pengrebongan Kesiman Denpasar, di Desa Adat Tampaksiring, di Pura Pengukur-ukuran Pejeng Gianyar, di Desa Singapadu Gianyar, di Desa Adat Apuan Tabanan, di Pura Pucak Padang Dawa Baturiti Tabanan. Dalam hal ini penulis mengangkat pelaksanaan Tradisi Patangkilan Barong di Pura Penataran Agung Puri Agung Singapadu, Kecamatan Sukawati, Kabupaten Gianyar. Tradisi Patangkilan Barong ini berlangsung setiap hari Budha Kliwon Pahang. Tradisi pertemuan belasan barong dalam berbagai jenis yang datang dari berbagai desa di Bali ini, memperlihatkan kompleksitas nilai-nilai spiritual, sosial, seni dan budaya masyarakat Bali. Pertemuan barong- barong ini memperlihatkan adanya ikatan sepiritual, hubungan sosial, persaudaraan, sejarah dan kekerabatan, serta kaitan kultural dari warga penyungsung masingmasing barong dengan warga penyungsung Pura Penataran Agung Singapadu, yang sudah berlangsung sejak dahulu kala.

Tradisi Patangkilan Barong ini melibatkan barong-barong dan rangda yang memiliki saling keterkaitan antara satu barong dengan barong maupun rangda lainnya yang dapat dibedakan berdasarkan : barong yang berasal dari satu bahan kayu yang sama, barong yang dibuat oleh sangging/undagi Puri Singapadu, barong yang memperoleh kekuatan magis dari satu tempat pasupati, barong yang memiliki kaitan dengan desa penyungsung barong. Pertemuan barong berdasarkan dari seorang undagi atau sangging yang sama, terjadi manakala punggalan bahkan keseluruhan 
barong dikerjakan oleh seorang sangging yang ahli dibidang penggarapan barong. Selain ahli, seorang sangging juga memiliki kemampuan lahir batin untuk mematikan dan menghidupkan kembali kekuatan kayu, sejak dari ngepel kayu, makalin, memahat, ngalusin, sesuai bentuk yang diinginkan, hingga memulas berdasarkan karakter dewanya, seperti Dewa Brahma, Visnu, Isvara dan lainnya. Setelah punggalan terwujud, maka proses selanjutnya adalah ritual pemelaspas, menghapus noda-noda selama dalam pengerjaan. Kemudian melangkah upacara ngatep artinya kepala dengan badan barong disambung atau disatukan. Pada tingkat selanjutnya barong dipasupati hingga tingkat mesuci atau ngerehin, yaitu memohon kekuatan gaib sebagai upaya untuk memasukkan daya hidup dari getaran energi alam kepada barong. Barong-barong yang dikerjakan dari sangging diyakini oleh masyrakat pendukung yang memiliki ikatan persaudaraan sehingga membangkitkan kesadaran kelompok religius yang mengalir dari satu sangging yang sama ini seperti halnya barong di Pura Tamansari Sanur dan barong di Pura Pura Puseh Sading Mengwi, yang dibuat oleh Ida Tjokorda Api Singapadu, (Pandji, 1975/1976: 28-56 dan Segara, 2002: 22-29 dalam Disertasi I Wayan Dana 2009).

Petangkilan barong di Pura Penataran Agung Puri Agung Singapadu adalah berdasarkan undagi atau sangging dan tempat pasupati dimana barong-barong yang ngerauhin atau lunga sinarengan adalah pekaryan atau buah karya Ida Tjokorda Api dan penerusnya diantaranya Ida Tjokorda Anom Api atau Ida Dwagung Geni dan Ida Dwagung Singapadu(Ida Tjokorda Oka Tublen). Ida Dwagung Geni ada beberapa yang nunas taksu atau mepasupati di Pura Penataran Agung Singapadu. Ida Tjokorda Api adalah seorang undagi/sangging putra Ida Dalem Sukawati (Ida Sri Dewa Agung Dalem Anom Sri Wijaya Tanu), yang merupakan lelangit Puri Agung Singapadu. Untuk lebih memperdalam akan Patangkilan Barong di Pura Penataran Agung Puri Agung Singapadu yang kebanyakan merupakan karya Ida Dewa Agung Api atau Ida
Tjokorda Api dan penerusnya lebih lanjut diungkapkan perihal Ida Tjokorda Api yang disarikan dari Babad Dalem Deruwen Ida Tjokorda Gede Agung Puri Kaleran Sukawati dalam Aksara Bali yang disalin dengan huruf latin oleh Pasikian Semeton Kawit Tunggal Dalem Sukawati tahun 1981.

Diceritakan daerah Sangsi wilayah Sukawati paling barat yang diperintah oleh I Dewa Kaleran dan setelah sekian lama karena merasa dirinya sudah tua serta kemungkinan tidak mempunyai penerus berkeinginan kembali untuk berkumpul dengan keluarganya di Sukawati, sehubungan dengan itu beliau memohon agar Ida Dalem Sukawati berkenan menempatkan seorang putranya untuk bertahta di Sangsi. Karena memiliki putra yang patut untuk bertahta di Sangsi, akhirnya Ida Dalem Sukawati memberikan istrinya yang sedang hamil tiga bulan untuk di ajak ke Sangsi supaya nantinya lahir di sana. Akhirnya lahirlah bayi laki-laki namun berperawakan hitam legam, tidak tampan dan pendek tidak seperti perawakan anak seorang raja. Akhirnya karena disangsikan kebenarannya I Dewa Kaleran menghadap kembali kepada Ida Dalem Sukawati, dan oleh dalem diberikan perintah untuk menguji kebenaran putra Ida Dalem Sukawati dengan membakarnya dengan bara api dari batok kelapa. Karena sang jabang bayi tidak terbakar maka dipercayalah putra ini merupakan benarbenar putra Ida Dalem Sukawati yang selanjutnya bernama Ida Dewa Agung Api atau Tjokorda Api.

Disebutkan juga Ida Dewa Agung Api bertahta di Puri Singapadu dan I Dewa Kaleran manca di Desa Sangsi. Beliau Ida Tjokorda Api pintar membuat barong, topeng dan patung, namun beliau tidak mempunyai putra dan mengangkat putra dari kakaknya Ida Sri Dewa Agung Dalem Mayun di keraton Sukawati bernama Ida Tjokorda Anom yang dipanggil Ida Tjokorda Anom Api yang juga pintar membuat barong, patung. Ida Tjokorda Anom Api banyak membuat barong dan rangda diantanya: barong di Kederi Singapadu. Barong di Desa Celuk, Barong 
di Desa Guwang Sukawati (Babad Dalem, 1981: 108-109).

Agama Hindu mengenalkan umatnya beragam kreasi lambang atau simbol sebagai jalan untuk berdialog dengan tuhan yang mereka puja. Lambang atau simbol bisa dalam wujud benda, tulisan, dan bahasa yang saling berbeda. Namun demikian, dalam ajaran Agama Hindu tetap pada hakekatnya adalah satu yaitu percaya kepada ada satu Tuhan. Budaya Hindu menerjemahkan bahwa ajaran Agama Hindu bersifat luwes dan fleksibel, memelihara serta menumbuhkan kreasi setiap umatnya dalam setiap meyakini Sang Hyang Widhi Wasa sesuai tempat, waktu dan situasi, hal ini mengantarkan umat Hindu yang berkembang di Bali memiliki kekayaan kreasi simbol yang bermuatan religius, etika, dan estetika tinggi (Wiana, 1993; 2428). Barong bagi masyrakat Bali selain dipercaya sebagai pelindung, juga diyakini sebagai simbol yang melambangkan kebaikan yang memiliki spirit ritual keagamaan dan digunakan sebagai sarana penyucian alam semesta. Kekuatan magis barong biasanya terletak pada punggalan khususnya mata, gigi dan bulu janggut barong yang di buat dari rambut manusia.

Kehidupan budaya masyarakat Bali masa kini memang memerlukan kesadaran dan kesungguhan semua lapisan masyarakat baik para seniman, budayawan, akademisi khususnya bidang Agama Hindu, seni, terus berprestasi dan kreatif. Hal ini didukung oleh penyungsung barong yang selalu menyimak kembali unsur-unsur positif tradisi dan budaya agama. Kesenian Bali termasuk berbagai pelaksanaaan pertunjukkan, seperti Tradisi Patangkilan Barong di Pura Penataran Agung Singapadu menjadi daya tangkal dan benteng pembelajaran serta menumbuhkan kesadaran toleransi positif masyarakat Bali. Aktivitas Patangkilan Barong berlangsung terus dan umumya tetap beroriaentasi serta berlandaskan aspek falsafah, upacara, dan estetika yang diperkaya oleh budaya lokal genius, yaitu keunggulan budaya setempat. Bagi kelompok-kelompok masyarakat di Bali tetap percaya bahwa Pura Penataran Agung mampu menyatukan strata sosial keberagaman khususnya warga penyungsung barong yang mengikuti Patangkilan Barong.

Tradisi Patangkilan Barong merupakan salah satu upacara ritual sebagai benteng dan ketahanan budaya dari desakan kehidupan masa kini. Pelaksanaan petangkilan barong memuat dimensi ritual seni maupun seni ritual atau terungkap kedua-duanya secara seimbang, sehingga menuntun kerahayuan bagi kehidupan masyarakat. Muatan-muatan itu menjadi daya pikat untuk digali, diramu lebih mendalam, sehingga menarik diungkap kembali dalam penelitian ini.

\section{METODE PENELITIAN}

Penelitian ini dirancang menggunakan metode kualitatif dan menekankan kepada analisis deskriptif kualitatif yang dimaksud untuk memahami fenomena tentang apa yang dialami oleh subjek penelitian misalnya perilaku, persepsi, motivasi, tindakan, dan lain-lain secara holistik, dan dengan cara deskripsi dalam bentuk kata-kata dan Bahasa, padasuatu konteks khusus yang alamiah dan dengan memanfaatkan berbagai metode alamiah (Moleong. 2013:6). Pengumpulan data dilakukan melalui observasi, wawancara secara mendalam dan studi kepustakaan yang dikelompokkan kedalam kategori-kategori tertentu yang mengacu pada pokok-pokok bahasan yang ditetapkan. Penelitian ini juga menggunakan teori diantaranya: teori fungsionalisme struktural, teori nilai, teori simbol, dan teori religi.

\section{PEMBAHASAN}

\subsection{Pelaksanaan Tradisi Patangkilan Barong di Pura Penataran Agung Singapadu Pada Hari Budha Kliwon Pahang}

Pada Hari Budha Kliwon Pahang merupakan hari pujawali di Pura Penataran Agung. Selain itu hari Budha Kliwon Pahang juga diyakini sebagai dewasa ayu untuk mempertemukan benda-benda sakral seperti barong dan rangda. Sama seperti halnya pelaksanaan Paruman Barong di 
Pura Pucak Padang Dawa Tabanan yang juga bertepatan dengan hari Budha Kliwon Pahang. Hal itu memang sudah berlangsung dari dulu dan hingga sekarang masih diwariskan oleh masyarakat pengempon Pura Penataran Agung Singapadu. Patangkilan Barong pada Hari Budha Kliwon Pahang karena pada hari itu merupakan puncak pujawali di Pura Penataran Agung dan tapakan barong yang ngerauhin pada saat pelaksanaan pujawali merupakan buah karya Ida Dewa Agung Api lelangit Puri Agung Singapadu dengan generasi penerusnya. Sehari sebelum Hari Budha Kliwon Pahang atau sehari sebelum puncak pelaksanaan Patangkilan Barong, pada hari ini dilakukan prosesi ritual dari pagi yaitu mecaru, nedunang pralingga Ida Bhatara Ring Penataran Agung, Ngiasin (menghias Pralingga Ida Bhatara) dan menyambut kedatangan seluruh tapakan Barong Ida Ratu Gede Tegeh Baturiti Tabanan, Ida Ratu Gede Guwang Sukawati, Ida Ratu Gede Puaya, Ida Ratu Gede Siangan, Ida Ratu Gede Celuk Sukawati, Ida Ratu Gede Keliki Tegalalang, Ida Ratu Lingsir Banjar Kebon Singapadu, Ida Ratu Agung Banjar Mukti Singapadu, Ida Ratu Mas Banjar Sengguan Singapadu, Ida Ratu Anom dan terakhir Ida Ratu Gede Kederi Singapadu Tengah yang secara silih berganti menyatu di Pura Penataran Agung Singapadu. Seluruh tapakan barong matur piuning ring ajeng Ida Ratu Sakti dan dihaturkan sesaji berupa segehan dan canang pengenteg linggih.

\subsection{Tapakan Barong Karya Sangging Puri Singapadu \\ Dalam bidang seni rupa Pura} Penataran Agung diyakini sebagai tempat Ida Dewa Agung Api lelangit Puri Singapadu dan generasi penerusnya menciptakan barong-barong keramat yang tersebar di beberapa tempat diantaranya : Barong Ket yang disakralkan dimuliakan, diagungkan di Desa Tegeh Kecamatan Baturiti, Kabupaten Tabanan, Barong Ket yang dimuliakan di Desa Antapan Tabanan, Barong Ket Yang di Sungsung di Pura Taman Sari, Desa Tojan, Klungkung, Barong Ket Yang di Sungsung di Desa Serongga Gianyar, Barong Ket yang ada di
Banjar Puaya Sukawati Gianyar, Barong Ket yang di Sungsung di Antap Tabanan, Barong Ket Yang di Sungsung di Desa Pekraman Serangan, Barong Ket yang ada di Gria Delod Pasar Desa Sanur, Denpasar Barong Ket yang di Sungsung di Banjar Tengah Peliatan, Barong Ket yang di Sungsung di Gria Dalem di Sibang Badung, Barong Ket di Pura Bukit dan Puri Bitra Gianyar. Barong Ket hasil karya Ida Dewa Agung Api pada umumnya berwajah angker atau aeng yang membuat orang merasa ketakutan dan tergetar ketika melihatnya, terutama dalam posisi diam di tempat penyimpanannya. Wajah Barong angker ini konon sangat dipengaruhi selera artistik Ida Dewa Agung Api yang lebih menyukai topeng-topeng yang berbau mistik, secara visual memiliki keunikan kalau dilihat dari belakang polanya berbentuk setengah lingkaran seperti saab bora mesibak penutup sesaji terbuat dari anyaman lontar yang dibelah dua(Dibia, 2011:5).

Ida Tjokorda Anom Api atau dikenal juga dengan nama Ida Dwagung Geni banyak membuat barong dan rangda diantaranya: Sasuhunan barong di Banjar Kederi Singapadu. Sasuhunan Barong di Desa Celuk, Sasuhunan Barong di Desa Guwang Sukawati. Ida Dwagung Singapadu atau Tjokorda Oka Tublen membuat Sasuhunan barong Ratu Putra di Desa Guwang, Sasuhunan Ratu Putra di Banjar Sengguan Singapadu, Ratu Putra di Kutri singapadu, Sasuhunan Barong Ket di Banjar Benawah, Sasuhunan Barong Ket di Belayu Tabanan, Sasuhunan Barong Ket di Semita Gianyar. Tjokorda Raka Tisnu generasi keempat Sangging Barong Puri Singapadu membuat Sesuhunan Rangda di Pura Desa Celuk, Sasuhunan Rangda Ratu Anom di Pura Dalem Gede Singapadu, Sasuhunan di Pura Prapat Nunggal, Sasuhunan Barong dan rangda di Puri Agung Buleleng, Sasuhunan Barong bangkal di Banjar Kebalian Sukawati, Sasuhunan barong dan rangda di Desa Nungnungan Plaga, Petang Badung. Generasi Sangging Barong di Puri Singapadu tetap setia melanjutkan warisan leluhurnya dengan belajar dan menjadikan karya-karya nenk moyangnya sebagai 
sumber inspirasi dan tetap lestari hingga kini.

\subsection{Prosesi Ritual Tradisi Patangkilan Barong di Pura Penataran Agung Singapadu}

Tepat pada hari Budha Kliwon Pahang merupakan bagian inti atau puncak pelaksanaan Patangkilan Barong semua tapakan barong dihaturkan sesaji lengkap serangkaian ritual odalan. Setelah rangkaian odalan selesai pada malam hari seluruh tapakan barong yang mengikuti Patangkilan Barong tedun mesolah ataษ5 napak pertiwi. Pada saat Pujawali para penyungsung barong dari manca desa secara bergantian menghaturkan sesaji kepada tapakan barongnya masing-masing maupun tapakan barong yang lainnya yang berada atau melinggih di areal Pura Penataran Agung. Silih berganti para penyungsung menghaturkan sesaji dari jeroan Pura Penataran Agung. Pada saatsaat seperti itu fungsi para pecalang sangat penting untuk mengatur ketertiban dan kelancaran para pemedek dalam menjalankan puja persembahan, sebagai wujud rasa syukur serta bhakti mereka kepada pemberi hidup. Pada hari manis, paing, dan ketelun Pujawali dilaksanakan napak pertiwi Ida Sasuhunan, seluruh sesuhunan mesolah diiringi oleh penabuh dan juru bapang masing-masing bagaikan festival budaya yang sangat magis dan religious yang dihadiri oleh seluruh penyungsung Sasuhunan yang dirangkaikan dengan pertunjukan prembon sebagai seni ritual yang biasanya mengambil cerita tentang sejarah terciptanya barong karya Ida Tjokorda Api.

\subsection{Nilai-nilai Pendidikan, Seni dan Budaya Yang Terkandung Dari Tradisi Patangkilan Barong di Pura Penataran Agung Singapadu}

Nilai pendidikan yang dapat diambil dari Patangkilan Barong di Pura Penataran Agung Singapadu adalah nilai Pendidikan Tattwa, Etika, Upacara, Nilai Pendidikan Kedamaian, Nilai Pendidikan Sraddha, Nilai Pemersatu Sosial, dan Nilai Religius
Magis. Hal tersebut dapat menyebabkan pelaksanaan Yadnya di Pura Penataran Agung Singapadu semakin bermakna. Kegiatan Petangkilan Barong ini mampu menjadi tali pengikat persaudaraan yang sangat kuat, dan membangun kesadaran kolektif di antara penyungsung barong. Hal ini disadari pula bahwa mereka senantiasa merasa yakin telah memperoleh kesegaran baru setiap upacara ritual ini berlangsung. Pelaksanaanya yang dirangkaikan dengan Napak Pertiwi, sebagai seni ritual semua sesuhunan mesolah dengan diiringi juru bapang dan penabuh dari masing-masing daerah penyungsung serta dilengkapi pementasan prembon yang mengisahkan rangkaian sejarah bagaimana terwujudnya Sasuhunan yang dibuat oleh Ida Tjokorda Api, hal ini menjadikan selama pelaksanaan bagaikan festival budaya yang magis dan religius yang menjadi sumber inspirasi bagi masyarakat. Dari wujud Sasuhunan yang merupakan karya seni yang adiluhung menjadikan daya kreatif yang melahirkan banyak sangging, maestro, seniman, pengarajin di Desa Singapadu sekitarnya sehingga tercipta karya yang agung dan metaksu, serta tentunya menjadi sumber mata pencaharian sehingga menghadirkan kesejahteraan.

\section{PENUTUP}

Berdasarkan pembahasan dapat disimpulkan bawa tradisi Patangkilan Barong di Pura Penataran Agung Singapadu dilaksanaan pada hari Budha Kliwon Pahang merupakan hari pujawali di Pura Penataran Agung. Selain itu hari Budha Kliwon Pahang juga diyakini sebagai dewasa ayu untuk mempertemukan benda-benda sakral. Tradisi Patangkilan Barong di Pura Penataran Agung Singapadu dihadiri tapakan barong yang ngerauhin pada saat pelaksanaan pujawali yang merupakan hasil karya Ida Dewa Agung Api lelangit Puri Agung Singapadu dengan generasi penerusnya. Patangkilan Barong ini melibatkan barong-barong dan rangda yang memiliki saling terkaitan, barong yang berasal dari satu bahan kayu yang sama, barong yang dibuat dari sangging/undagi Puri Singapadu, barong yang memperoleh kekuatan magis dari satu 
tempat pasupati, barong yang memiliki kaitan dengan desa penyungsung barong. Nilai Pendidikan, seni dan budaya yang dapat diambil dari Patangkilan Barong di Pura Penataran Agung Singapadu adalah pendidikan tattwa, etika, upacara, nilai pendidikan kedamaian, nilai pendidikan sraddha, nilai pemersatu sosial, dan seni budaya yang terkandung didalamnya sebagai seni ritual bernilai religius magis yang menjadi sumber inspirasi yang menghasilkan kemasyuran dan kesejahteraan.

\section{DAFTAR PUSTAKA}

Dibia, I Wayan. 2011 Mask Taksu of Singapadu. Singapadu: Rumah Dokumen.

Dibia, I Wayan. 1991. Selayang Pandang Seni Pertunjukan Bali. Bandung: MSPI.

Dana, Wayan. 2009. Paruman Barong di Puncak Padang Dawa. Denpasar: UNUD.

Gede Agung, Ida Tjokorda. 1981. Babad Dalem. Denpasar: Percetakan Aksara.

Moleong, Lexy J.2013. Metodelogi Penelitian Kualitatif, Edisi Revisi. Bandung: PT. Remaja.

Wiana, I Ketut. 2007. Tri Hita Karana Menurut Konsep Hindu. Surabaya : Paramita 